Jurnal Analis Laboratorium Medik

Avalilable Online http://e-journal.sari-mutiara.ac.id/index.php/ALM

\title{
SISTEM PEMANTAUAN PH, TEMPERATUR DAN KELEMBABAN PADA PEMBUATAN PUPUK KOMPOS
}

\author{
Tuful Zuchri' ${ }^{1}$, Ana Uzla Batubara ${ }^{2}$, Adiansyah ${ }^{3}$ \\ ${ }^{1}$ Program Studi Teknologi Elektromedis, STIKES Binalita Sudama \\ ${ }^{2}$ Program Studi Keperawatan,STIKES Binalita Sudama \\ ${ }^{3}$ Program Studi Kimia, Fakultas Sain, Teknologi dan Informasi, USM-Indonesia \\ Email: tufulregar88@gmail.com
}

\begin{abstract}
ABSTRAK
Telah dilakukan penelitian tentang sistem pemantauan $p H$, Temperatut dan kelembaban pada pembuatan pupuk kompos. Peralatan ini sangat dibutuhkan oleh para petani untuk mengontrol pembuatan pupuk kompos untuk hasil yang lebih maksimal. Hasil penelitian menunjukkan bahwa sensor YL-69, display $L C D$, arduiono uno dan pembacaan dengan software yang dihubungkan dengan MySql mampu terkoneksi dengan baik. Dari hasil penelitian ini didapatkan ketelitian sudah mendekati hasil senbenarnya dimana semisal nilai $20 \%$ makan akan didapatkan hasil sebesar +/- 2,80\% untuk sebuah nilai kepastian sedangkan ketidakpastian untuk suhu nilai maksimal 3 dan dalam pembaaan $\left(70^{\circ} \mathrm{C}+/-3^{\circ} \mathrm{C}\right)$.Dari hasil penelitian yang diproleh menunjukkan bahawa alat yang digunakan sudah bisa digunkan untuk sistem monitoring pH, temperatur dan kelembaban untuk optimalisasi pembuatan pupuk kompos dengan bemberian air yang sesuai dengan fan yang digunakan untuk pembuatan pupuk kompos.
\end{abstract}

Kata Kunci : Alat monitoring pH; Alat Monitring Suhu; Alat Monitoring kelembaban; Pupuk Kompos. 


\section{PENDAHULUAN}

Sistem monitoring pada pembuatan pupuk sangat dibutuhkan untuk memperoleh hasil yang mak simal terutama untuk $\mathrm{p}$ etanian dan perk ebunan walaupun itu hanya untuk hobi ataupun produksi. Beberapa aspek yang perlu diperhatik an adalah temperatur dan kelembaban. Fertilizer maker adalah merupakan salah satu alat yang dibuat untuk proses produksi pupuk yang dilengkapi dengan proses pemanasan dan pengaturan kelembaban pupuk ${ }^{1-3}$.

Berbagai masalah yang dihadapi petani adalah kekurangan nutrisi makro seperti $\mathrm{N}, \mathrm{P}, \mathrm{K}$ maupun kekurangan nutrisi mikro seperti $\mathrm{Ca}, \mathrm{Fe}, \mathrm{Mn}$, dan lainnya. Hal ini menjadi tantangan yang harus diahapi petani saat ini. kekurangan nutrisi tersebut dapat mengalami perubahan warna dan terkadang dari pertumbuhan serta bentuk daun muda dapat dilihat secara langsung pada tanaman. Faktor kekurangan nutrisi tersebut menjadi masalah penting maka diperlukan pengukuran dan monitoring untuk dapat menjaga $\mathrm{pH}$, kelembaban dan suhu pada alat fertilizer maker $^{1,4,7,8}$.

Pupuk sangat dibutuhkan oleh petani dalam menambah unsur hara pertumbuhan tanaman. penggunaan pupuk bahan organik tersebut adalah mengurangi masalah yang sekarang timbul akibat dipakainya bahan-bahan kimia yang telah terbukti merusak tanah dan lingkungan, merusak keseimbangan unsur hara dalam tanah serta menurunkan kualitas tanah. Untuk itu diperlukan pupuk organik untuk membantu upaya pemulihan kesuburan $\operatorname{tanah}^{8-10}$.

Dalam pembuatan pupuk organik, bakteri merupkan salah satu mikroorganisme yang berperan penting. Oleh karena itu,

\section{Universitas Sari Mutiara Indonesia}

DOI: https://doi.org/10.51544/jalm.v6i2.2232 dibutuhkan suatu perancangan alat untuk mengetahui temperatur dan k elembaban pada alat fertilizer maker. Pada penelitian yang sudah dilakukan, perancangan sistem monitoring temperatur dan kelembaban dilakukan dengan menggunakan sensor $Y L$ 69, Thermocouple, Arduinouno, display LCD dan akuisisi data dengan menggukanan software visual basic 2015 yang sudah terkonek si database MySQL.

Pupuk organik merupakan pupuk yang bersumber dari bahan-bahan organik melalui proses pengomposan. Dalam proses pembuatan pupuk organik dilakukan dengan dua tipe yaitu melalui proses pengomposan. Tahap 1: Pupuk organik dibuat dengan melarutkan pupuk organik ke dalam air, bisa berupa pupuk hijau, pupuk kandang, pupuk kompos atau campuran semuanya. Tahap 2: Pupuk organik terdiri dari bahan-bahan organik melalui proses fermentasikan dalam kondisi anaerob dengan bantuan organisme hidup. Unsur hara yang terkandung dalam larutan pupuk tipe ini benar-benar berbentuk padatan. Jadi larutannya lebih stabil. Bila dibiarkan tidak mengendap. Oleh karena itu, sifat dan karakteristiknya pun berbeda dengan pupuk yang dibuat dari pupuk padat dan yang dilarutkan ke dalam air ${ }^{9-15}$.

Carbon $(\mathrm{C})$ maupun Nitrogen $(\mathrm{N})$ juga berfungsi untuk menyeimbangkan ketersediaan nitrogen yang dapat dimanfaatkan oleh tanaman. Apabila bahan organik yang diberikan ke tanah mempunyai kandungan $\mathrm{C} / \mathrm{N}$ yang tinggi, mikroorganisme tanah dan tanaman akan berkompetisi memanfaatkan kandungan tersebut dan karbohidrat yang dijadikan sebagai sumber energi dan pertumbuhan mikroba, ternyata juga memmerlukan $\mathrm{N}$ dan Posfor (P). Melalui tahapan ini protein tumbuhan dialihkan menjadi protein mikroba rasio $\mathrm{C} / \mathrm{N}$ 
yang efektif untuk proses pembuatan pupuk berkisar antara 30:1 hingga 40:1. Pada rasio $\mathrm{C} / \mathrm{N}$ di antara 30 hingga 40, mikroba mendapatkan cukup $\mathrm{C}$ untuk energi dan $\mathrm{N}$ untuk sintesis protein. Apabila rasio $\mathrm{C} / \mathrm{N}$ terlalu tinggi, mikroba akan kekurangan $\mathrm{N}$ untuk sintesis protein sehingga dekomposisi lambat. Selama proses itu, rasio $\mathrm{C} / \mathrm{N}$ akan terus menurun. Pupuk yang langsung dapat digunakan memiliki rasio $\mathrm{C} / \mathrm{N}$ nya kurang dari 20. Total kandungan $\mathrm{C}$ dalam unsur hara tanah adalah 56.24\%. Sementara itu Kadar N dalam protein adalah $16 \%$, sedangkan unsur hara mengandung 35\%protein, jadi kadar $\mathrm{N}$ dalam unsur hara adalah $35 \times 0.16=5.6 \%$. Oleh karena itu hasil bagi $\mathrm{C} / \mathrm{N}$ rata-rata adalah $56.24 / 5.6=10.04 \%^{6,8,10,13}$.

Pupuk yang sudah matang memiliki kandungan hara kurang lebih: $1,69 \% \mathrm{~N}$, $0,34 \% \mathrm{P} 2 \mathrm{O} 5$, dan $2,81 \% \mathrm{~K}$. dengan kata lain, dalam seratus liter pupuk setara dengan 1,69 liter urea, 0,34 liter SP-36, dan 2,81 liter KCl. Nitrogen (N) berperan penting dalam merangsang pertumbuhan vegetatif dari tanaman. Selain itu N merupakan penyusun plasma sel dan berperan penting dalam pembentukan protein. Fosfor adalah unsur hara makro kedua setelah nitrogen yang banyak dibutuhkan tanaman untuk pertumbuhannya dan diserap tanaman dalam bentuk ion. Sumber utama fosfor di dalam tanah berasal dari pelapukan mineral-mineral yang mengandung fosfat. Kalium (K) adalah unsur hara makro yang banyak dibutuhkan tanaman, dan diserap tanaman dalam bentuk ion $\mathrm{K}+$. Di dalam tubuh tanaman kalium bukanlah sebagai penyusun jaringan tanaman, tetapi lebih banyak berperan dalam proses metabolisme tanaman seperti mengaktifkan kerja enzim, membuka dan menutup stomata, transportasi ${ }^{9-15}$.

\section{Universitas Sari Mutiara Indonesia}

DOI: https://doi.org/10.51544/jalm.v6i2.2232
Kelembaban merupakan suatu tingkat keadaan lingkungan udara basah yang disebabkan oleh adanya uap air. Tingkat kejenuhan sangat dipengaruhi oleh temperatur. Grafik tingkat kejenuhan tekanan uap air terhadap temperatur.

$\mathrm{pH}$ adalah derajat keasaman yang digunakan untuk menyatakan tingkat keasaman atau kebasaan yang dimiliki oleh suatu larutan. $\mathrm{pH}$ didefinisikan sebagai kologaritma aktivitas ion hidrogen $(\mathrm{H}+)$ yang terlarut. Koefisien aktivitas ion hidrogen tidak dapat diukur secara eksperimental, sehingga nilainya didasarkan pada perhitungan teoritis. Skala $\mathrm{pH}$ bukanlah skala absolut. Ia bersifat relatif terhadap sekumpulan larutan standar yang pH-nya ditentukan berdasarkan persetujuan internasional. Air murni bersifat netral, dengan $\mathrm{pH}$-nya pada suhu $25{ }^{\circ} \mathrm{C}$ ditetapkan sebagai 7,0. Larutan dengan $\mathrm{pH}$ kurang daripada tujuh disebut bersifat asam, dan larutan dengan $\mathrm{pH}$ lebih daripada tujuh dikatakan bersifat basa atau alkali. Pengukuran $\mathrm{pH}$ sangatlah penting dalam bidang yang terkait dengan kehidupan atau industri pengolahan kimia seperti kimia, biologi, kedokteran, pertanian, ilmu pangan, rekayasa (keteknikan), dan oseanografi. Tentu saja bidang-bidang sains dan teknologi lainnya juga memakai meskipun dalam frekuensi yang lebih rendah. Secara umum, sistem pengukuran disusun atas beberapa tahap, dan tahapan tersebut dijelaskan dengan diagram blok. Diagram blok sistem pengukuran terdiri atas empat aspek utama, yaitu sensing element, signal conditioning element, signal processing element dan data presentation element. Berikut ini penjelasan dari diagram blok sistem pengukuran. ${ }^{4,8,13,15}$. 


\section{METODE PENELITIAN}

Penelitian ini

dilakukan

dilaboratorium teknologi elektromemedis STIKES Bainalita Sudama dan Laborium Teknologi Elektromedis USM-Indonesia. Adapun alat yang digunakan adalah Sensor YL-69, mikrocontroler ardino mega 2560, LCD visual studio 2015, sensor termocopel, intergrasi hardware dan software, PC dengan studio visual. Adapun tahapan-tahapan penelitian dilakukan dengan studi literaurnalat ukur $\mathrm{pH}$, temperatur dan kelembaban, perancangan pembuatan hardware serta software dengan alat ukur $\mathrm{pH}$, temperatur dan kelembaban hasil yang diproleh di ientegasikan dengan hardware dan software pemograman, desain tampilan pada PC dengan visual studio 2013 dan mendia penyimpanan pada databese serta analisis data dan penarikkan kesimpulan.

\section{HASIL DAN PEMBAHSANAN}

Dalam proses penelitian ini mengkalibrasi alat sangat sering dilakukan pada sensor karena hal tersebut sangat berpengaruh terahap hasil yang akan diproleh.
Hasil yang dirpoleh yang disajikan pada data berikut merupakan hasil dari kalibrasi pada thermocouple pada alat thermometer. Kalibrasi pada pemeriksaan alat sebagai berikut:

\begin{tabular}{|cccc|}
\hline No & $\begin{array}{c}\text { Hasil } \\
\text { Data } \\
\text { Pada Alat }\end{array}$ & Standart & Koreksi \\
\hline $\mathbf{1}$ & 33.20 & 30 & $-3,20$ \\
\hline $\mathbf{2}$ & 33.23 & 30 & -2.23 \\
\hline $\mathbf{3}$ & 33.22 & 30 & $-3,22$ \\
\hline $\mathbf{4}$ & 33.23 & 30 & $-3,23$ \\
\hline $\mathbf{5}$ & 33.20 & 30 & $-3,20$ \\
\hline Jumlah & 166,08 & 150 & $-16,08$ \\
\hline Rata-rata hasil & 33,216 & 30 & $-3,22$ \\
\hline \multicolumn{4}{c}{ Nilai Minimum } \\
\hline \multicolumn{4}{c}{ Nilai maksimum } \\
\hline
\end{tabular}

Dalam penelitian ini pada pembacaan alat selalu dilakukan kalibrasi dengan pengulangan sebbanyak 5 kali untuk memproleh hasil yang makasimal. Dari hasil penelitian yang diproleh nilai $\mathrm{UA}_{1}$ dan nilai $\mathrm{UA}_{2}$ dan UIB serta nilai UC dapat dilihat pada tabel berikut ini.

\begin{tabular}{|clllllllll|}
$\begin{array}{c}\text { No } \\
\text { Sampel }\end{array}$ & Hasil & \multicolumn{4}{c}{ Hasil Yang Diproleh Pada Data } & \multicolumn{2}{c|}{$\begin{array}{l}\text { Rata- } \\
\text { rata }\end{array}$} & Koreksi \\
\hline $\mathbf{1}$ & 30 & 1 & 2 & 3 & 4 & 5 & 33.20 & -3.20 \\
\hline $\mathbf{2}$ & 29.90 & 33.20 & 33.22 & 33.21 & 33.20 & 33.15 & 3.18 \\
\hline $\mathbf{3}$ & 29.98 & 33.15 & 33.15 & 33.20 & 33.22 & 33.21 & 33.18 & -3.18 \\
\hline & Jumlah & & & & 33.22 & 33.21 & 33.23 & 33.20 & -3.20 \\
\hline
\end{tabular}

Keterangan : $\quad \mathrm{UA}_{1}=$ Ketidakpastian pengukuran $\quad$ Untuk mendapatkan nilai UA2 diperlukan $\mathrm{UA}_{2}=$ Ketidakpastian regresi

$\mathrm{UB}_{1}=$ Ketidakpastian resolusi

$\mathrm{Uc}=$ Ketidakpastian cakupan nilai Yreg dengan nilai SSR sedangkan untuk nilai a dan $b$ dapat diperoleh dari tabel. Data hasil yang diproleh dapat dilihat pada tabel dibawah ini:

Uexpan $=$ Ketidakpatian diperluas

Yreg $=a+(b * t i)$

\begin{tabular}{|lllllll|}
\hline No & ti2 & ti* ${ }^{*}$ yi & Y regresi & Residu ${ }^{\odot}$ & SSR & Y2 (Kuadrat) \\
\hline $\mathbf{1}$ & 1243.2 & -110.53 & -9.55 & 6.71 & 45.20 & 8.07 \\
\hline $\mathbf{2}$ & 1311.4 & -111.5 & $-9,97$ & 7.65 & 55.19 & 7.58 \\
\hline $\mathbf{3}$ & & -114.6 & -10.98 & 6.72 & 60.32 & 8.08 \\
\hline
\end{tabular}

1.20 dan nilai $b=0,085$ dan nilai $S S R=$

$\mathrm{UA}_{2}=$ 150,5 yang diproleh pada persamaaan.

$\sqrt{\frac{S S R}{n-2}}=\sqrt{\left(\frac{150.5}{3-2}\right.}=$

Dalam proses pengukuran untuk kelembapan diproleh hasil sapan range dimana diproleh sebesar 99\%, dengan nilai presisi dan akurasi dari alat sensor yang digunkan. Dalam

Universitas Sari Mutiara Indonesia

DOI: https://doi.org/10.51544/jalm.v6i2.2232 
Tuful Zuchri et all| Sistem Pemantauan PH, Temperatur Dan Kelembaban Pada Pembuatan Pupuk Kompos

perhitungan kalibarasi pengulangan dilakukan sebanyak 5 kali untuk memperoleh hasil yang maksimal. Berikut data kalibrasi pada pemeriksaan alat yang diproleh :

\begin{tabular}{|c|c|c|c|}
\hline No & $\begin{array}{l}\text { Hasil data } \\
\text { pada alat }\end{array}$ & Standar (\%) & Kaoreksi \\
\hline 1 & 50.20 & 50 & $-0,20$ \\
\hline 2 & 50.21 & 50 & $-0,21$ \\
\hline 3 & 50.33 & 50 & $-0,33$ \\
\hline 4 & 50.30 & 50 & $-0,30$ \\
\hline 5 & 50.20 & 50 & $-0,20$ \\
\hline & \multicolumn{2}{|c|}{ Jumlah } & -1.24 \\
\hline & \multicolumn{2}{|c|}{ Rata-rata hasil } & 0,288 \\
\hline
\end{tabular}

Pembacaan alat pada standar deviasi didapat data sebagai berikut :

\begin{tabular}{|c|c|c|c|c|c|c|c|c|}
\hline \multirow[t]{2}{*}{ No } & \multirow[t]{2}{*}{ Standar } & \multicolumn{5}{|c|}{ Nilai Kc } & \multirow{2}{*}{$\begin{array}{l}\text { Rata- } \\
\text { rata }\end{array}$} & \multirow[t]{2}{*}{ Koreksi } \\
\hline & & 1 & 2 & 3 & 4 & 5 & & \\
\hline 1 & 0.5 & 0.24 & 0,23 & 0,24 & 0,23 & 0,32 & 0,25 & 0,25 \\
\hline 2 & 4 & 4.14 & 4.15 & 4.12 & 4.14 & 4.13 & 4.14 & 0,14 \\
\hline 3 & 5 & 5.10 & 5.11 & 5.80 & 5.11 & 5.12 & 5.13 & 0,13 \\
\hline 4 & 6 & 6.12 & 6.13 & 6.13 & 6.16 & 6.14 & 6.14 & 0,14 \\
\hline 5 & 8 & 8.15 & 8.70 & 8.14 & 8.85 & 8.89 & 8.55 & 0,55 \\
\hline
\end{tabular}

\section{Hasil pengukuran pH}

Dalam pengukuran $\mathrm{pH}$ dilakukan dalam 3 bagian laurutan buffer yaitu pada $\mathrm{pH} \mathrm{4,} 578$ dan 9 dengan

\begin{tabular}{|c|c|c|c|}
\hline No & $\begin{array}{c}\text { Hasil Yang Diperoleh } \\
\text { Pada Alat }\end{array}$ & Standart & Koreksi \\
\hline $\mathbf{1}$ & 7.05 & 7 & 0,5 \\
\hline $\mathbf{2}$ & 7.04 & 7 & 0,4 \\
\hline $\mathbf{3}$ & 6.89 & 7 & 0,11 \\
\hline $\mathbf{4}$ & $\mathbf{6 . 9 8}$ & $\mathbf{7}$ & $\mathbf{0 , 0 2}$ \\
\hline $\mathbf{5}$ & 7.03 & 7 & 0,3 \\
\hline Jumlah & 34.99 & 35 & 1.33 \\
\hline Rata-rata & 6.99 & 7.00 & 0,28 \\
\hline
\end{tabular}

Dari hasil penelitian diperoleh bahwa perbandingan pada $\mathrm{pH}$ meter dalam programing arduino dimana pembacaan yang diproleh sudah menunjukkan pendekatan dengan $\mathrm{pH}$ buffre yang diproleh pada sampel standar. Tahapan selanjutnya yang perlu dilakukan adalah dengan mengkalibrasi sesuai dengan standar yang dibutuhkan sehingga

\section{Universitas Sari Mutiara Indonesia}

DOI: https://doi.org/10.51544/jalm.v6i2.2232 sampel sebanyak 5 dengan 3 kali pengulangan. Data yang diperoleh disajikan pada tabel beriku ini. 
Tuful Zuchri et all| Sistem Pemantauan PH, Temperatur Dan Kelembaban Pada Pembuatan Pupuk Kompos

Hasil validasi data yang diproleh sebagai berikut :

\begin{tabular}{|c|c|c|c|c|c|c|c|c|}
\hline \multirow[t]{2}{*}{ No } & \multirow{2}{*}{$\begin{array}{l}\text { Pembacaan } \\
\text { standart }\end{array}$} & \multicolumn{5}{|c|}{ Hasil pembacaan alat } & \multirow{2}{*}{$\begin{array}{l}\text { Rata-rata hasil } \\
\text { pembacaan alat }\end{array}$} & \multirow{2}{*}{$\begin{array}{c}\text { Koreksi } \\
\text { (y) }\end{array}$} \\
\hline & & 1 & 2 & 3 & 4 & 5 & & \\
\hline 1 & 4 & 4.20 & 4.19 & 4.18 & 4.20 & 4.15 & 4.18 & 0.18 \\
\hline 2 & 5 & 5.10 & 5.15 & 5.15 & 5.18 & 5.10 & 5.13 & 0,13 \\
\hline 3 & 7 & 7.15 & 7.18 & 7.20 & 7.15 & 7.20 & 7.18 & 0,18 \\
\hline 4 & 8 & 8.96 & 8.91 & 8.88 & 8.72 & 8.75 & 8.84 & 0,84 \\
\hline 5 & 9 & 8.96 & 9.01 & 9.15 & 9.20 & 9.18 & 9.1 & 0,10 \\
\hline \multicolumn{7}{|c|}{ Jumlah } & 34.43 & 1,43 \\
\hline
\end{tabular}

Dalam penelitian ini menggunkan termocouple dan sensor YL-69.

\section{KESIMPULAN}

Dari hasil penelitian diproleh keluaran berupa data anolog yang dibaca pada sensing element dan humdity dan nilai akan dikeluarkan pada pembacaan mikrocontroler yang digunakan. Tahapan selanjutnya diproses pada arduiono mega dalam pembacaan LCD dan dengan menggunakan software interface. Dari hasil penelitian ini didapatkan ketelitian sudah mendekati hasil senbenarnya dimana semisal nilai 20\% makan akan didapatkan hasil sebesar +/- 2,80\% untuk sebuah nilai kepastian sedangkan ketidakpastian untuk suhu nilai maksimal 3 dan dalam pembaaan $\left(70^{\circ} \mathrm{C}+/-3^{\circ} \mathrm{C}\right)$.

Dari hasil penelitian yang diproleh menunjukkan bahawa alat yang digunakan sudah bisa digunkan untuk sistem monitoring $\mathrm{pH}$, temperatur dan kelembaban untuk optimalisasi pembuatan pupuk kompos dengan bemberian air yang sesuai dengan fan yang digunakan.

\section{UCAPAN TERIMAKASIH}

Peneliti mengucapakan terimakasih kepada Direktorat Riset dan Pengabdian Masyarakat Deputi Bidang Penguatan Riset dan Pengembangan Kementerian Riset dan Teknologi/ Badan Riset dan Inovasi Nasional, Kemendikbud Ristek yang telah memeberikan pendanaan Penelitian Dosen Pemula tahun 2020 pelaksanaan 2021 dan Kepada STIKES Binalita Sudama tempat peneliti mengabdikan diri.

Universitas Sari Mutiara Indonesia

DOI: https://doi.org/10.51544/jalm.v6i2.2232

\section{DAFTARA PUSTAKA}

Melati, H. P. (2014). Teknologi Pembuatan Pupuk Organik. Reuleut: Universitas Malikussaleh.

Bagus, T. P. (2012). Pengaruh Kelembaban Tanah Terhadap Tanaman. Sukabumi.

Bentley, J. P. (2005). Principles Of Measurement System (4nd Ed.). Essex, United Kingdom: Pearson Education Limited.

Firmansyah, O. A. Rancang Bangun Sistem Monitoring Dan Akuisisi Data Rpm Fan, Temperatur Dan Kelembaban Pada Ducting Air Conditioning Laboratory Unit Pa Hilton A575. Surabaya: ITS.

Laboratorium Pengukuran Fisis. (2014). Modul Teknik Pengukuran dan Kalibrasi. Surabaya: ITS.

Tirto, K. (2013). Dampak dan Pengaruh Kelembaban Terhadap Tanaman dan Nutrisi. Bogor

Harjanti, 2017. "Pupuk Organik dari Limbah Pabrik Gula Madukismo dengan Starter Mikrobia Pengurai Untuk Menambah Kandungan N, P, K”, Politeknik LPP, Yogyakarta.

Sinaga, Lidia Hana. 2019. "Monitoring Suhu dan Kelembaban Udara Menggunakan IoT (Internet of Things) Berbasis NodeMCU ESP8266". Universitas Sumatera Utara.

Hapsari, Chrismalia; Wilujeng, Susi Agustina. 2011. Studi Emisi Karbondioksia (CO2) dan Metana (CH4) Dari Kegiatan Reduksi Sampah 
Diwilayah Surabaya Bagian Selatan. Teknik Lingkungan, ITS. Surabaya.

Afrizal, M.A. 2018. Rancang Bangun Rumah Pintar Berbasis IOT (Internet of Things) Sebagai Media Pembelajaran pada Mata Pelajaran pemrograman, Mikroprosesor dan Mikrokontroller di SMKN2 Surabaya. Jurnal Pendidikan Teknik Elektro. Vol.7, No.1, pp.79-86.

Rahmawati, Novi, Dony, Novria. 2014. "Pembuatan Pupuk Organik Berbahan Sampah Organik Rumah Tangga Dengan Penambahan Aktivator Em4 di Daerah Kayu Tangi”. Fakultas Keguruan dan Ilmu Pendidikan Universitas Islam Kalimantan MAB Banjarmasin.

Palar, H. 1994. Pencemaran dan Toksikologi Logam Berat. Jakarta: Rineka Cipta

Siswanto, A 1991. Toksikologi Industri. Surabaya: Balai Hiperkes dan Keselamatan Depnaker jatim

Adryanto. 2005.Deteksi Pencemaran Timah Hitam $(\mathrm{Pb})$ dalam Darah, Masyarakat yang Terpajan Timbal (Plumbum), Jurnal Kesehatan Lingkungan Vol-2/No.1 